\title{
KARAKTERISTIK AKSEPTOR KONTRASEPSI INTRA UTERIN DEVISE POST PLACENTA DI PUSKESMAS WILAYAH KABUPATEN BANJARNEGARA TAHUN 2017
}

\author{
Ratih Subekti ${ }^{1}$, Lia Aria Ratmawati ${ }^{2}$ \\ ${ }^{1}$ Program Studi DIII Kebidanan Politeknik Banjarnegara \\ bektymidewife@gmail.com \\ ${ }^{2}$ Program Studi DIII Kebidanan Politeknik Banjarnegara \\ liaaria13@gmail.com
}

\begin{abstract}
The most ideal contraceptive for postpartum and breastfeeding mothers is not to suppress breast milk production such as Intra Uterine Device (IUD), 3 month injections of contraception, minipil and condom. The IUD is a flexible plastic contraceptive device placed in the uterus, whereas IUD post placenta is an IUD that is performed 10 minutes after birth or before uterine tailoring in the Section of Sesaria action.

The purpose of this research is to know the characteristics of IUD post placenta respondents in Puskesmas of Banjarnegara Regency in 2017. This research uses descriptive research method with Cross Sectional approach. The instrument used is a table for recapitulation of contraceptive IUD post placenta acceptor data obtained from RM Puskesmas. The number of samples is 38 respondents. Data analysis using univariate analysis.

The result of research is post placenta IUD acceptor age mostly in age group 20-35 years old that is 30 people (78.9\%), education of post placenta IUD predominant are mostly Senior High School and Academic / PT that is 20 people (52.7\%), parity acceptor post IUD placenta is mostly parity two that is as much as 20 people (52.6\%) and the job of post placenta IUD acceptors are mostly IRT counted 35 people (91.1\%). It is expected that health workers to improve family planning services through counseling and counseling to candidates KB post placenta IUD acceptors so that the number of acceptors can be improved.
\end{abstract}

Key Words: post placenta IUD, age, education, parity, job.

\section{PENDAHULUAN}

Masalah kesakitan dan kematian ibu di Indonesia masih merupakan masalah besar di negara ini. Berdasarkan Survei Demografi dan Kesehatan Indonesia (SDKI) 2007, angka kematian Ibu di Indonesia menunjukkan 248 per 100.000 kelahiran hidup. Angka ini masih perlu diturunkan lagi jika melihat angka target Millenium Development Goals (MDG's) tahun 2015, yaitu 102 per 100.000 kelahiran hidup. Salah satu program untuk menurunkan Angka Kematian Ibu adalah program Keluarga Berencana (KB). Program KB berperan dalam menurunkan angka kematian Ibu melalui upaya pencegahan kehamilan, penundaan usia kehamilan, dan menjarangkan kehamilan (BAPENAS, 2007).

Salah satu strategi dari pelaksanaan program KB sendiri seperti tercantum dalam Rencana Pembangunan Jangka Menengah (RPJM) tahun 2004-2009 adalah meningkatnya penggunaan Metode Kontrasepsi Jangka Panjang (MKJP) seperti IUD (Intra Uterine Device), implant (susuk) dan sterilisasi. IUD merupakan salah satu jenis alat kontrasepsi non hormonal dan termasuk alat kontrasepsi jangka panjang yang ideal dalam upaya menjarangkan kehamilan. Keuntungan pemakaian IUD yakni hanya memerlukan satu kali pemasangan untuk jangka waktu yang lama dengan biaya yang relatif murah, aman karena tidak mempunyai pengaruh sistemik yang beredar ke seluruh 
tubuh, tidak mempengaruhi produksi ASI dan kesuburan cepat kembali setelah IUD dilepas (BKKBN, 2009).

Menurut Survey Demografi Kesehatan Indonesia (SDKI) 2007, bahwa kontrasepsi yang banyak digunakan adalah metode suntik (31.8\%), pil (13.2\%), Alat Kontrasepsi Dalam Rahim (AKDR) 4.9\%, Metode Operatif Wanita (MOW) 3\%, kondom 1.3\%, dan Metode Operatif Pria (MOP) 0.2\%. Dapat dilihat bahwa presentase peserta KB MKJP masih tergolong rendah yang berarti pencapaian target program dan kenyataan di lapangan masih berjarak lebar. Bahkan prevalensi peserta AKDR menurun selama 20 tahun terakhir, dari $13 \%$ pada tahun 1991 menjadi $5 \%$ pada tahun 2007 (BPS, 2009).

Berbagai usaha di bidang gerakan KB sebagai salah satu kegiatan pokok pembangunan keluarga sejahtera telah dilakukan baik oleh pemerintah, swasta, maupun masyarakat sendiri. Salah satunya dengan mensosialisasikan metode kontrasepsi terkini IUD Post Placenta oleh BKKBN. Metode IUD Post Placenta mempunyai keuntungan tersendiri, selain pemasangannya lebih efektif karena dilakukan setelah plasenta lahir sekaligus mengurangi angka kesakitan Ibu. Pada hasil expert meeting tahun 2009 dikatakan bahwa penggunaan IUD post placenta dan post abortus perlu terus digalakkan karena sangat efektif, mengingat angka kelahiran rata-rata 4.000.000 per tahun (BKKBN, 2010).

Jumlah Pasangan Usia Subur (PUS) di Propinsi Jawa Tengah, sebanyak 5.652.038 orang dan yang menjadi peserta KB aktif sebanyak 4.706.510 $(83,3 \%)$ yang terdiri dari KB IUD 5.73\%, MOW 2.91\%, MOP 0.49\%, Implant $6.44 \%$, suntik $57.72 \%$, pil $8.92 \%$ dan kondom 1.06\%(BKKBN, 2016).

Jumlah peserta KB aktif di Kabupaten Banjarnegara tahun 2016 adalah 153.000 akseptor. Cakupan sasaran PUS menjadi peserta KB Aktif sebanyak 74.20\% (Rencana Pembangunan Jangka Menengah Daerah, 2011-2016).

Program pemerintah yang dianjurkan adalah metode kontrasepsi jangka panjang (MKJP) yang salah satunya IUD pasca plasenta (BKKBN, 2010). Pemilihan metode kontrasepsi menurut Bulatao (1989) dipengaruhi oleh empat faktor yaitu tujuan kontrasepsi (contraceptive goals), kompetensi kontrasepsi (contraceptive competence), evaluasi kontrasepsi (contraceptive). Tujuan kontrasepsi dipengaruhi oleh beberapa faktor seperti usia wanita, jumlah anak hidup, komposisi jenis kelamin anak, usia anak terkecil, jenis persalinan terakhir, usia pernikahan dan tujuan reproduksi (fertility intention) (Laguna, Po, Perez, 2000).

Usia mempengaruhi terhadap daya tangkap dan pola pikir seseorang. Semakin bertambah usia akan semakin berkembang pula daya tangkap dan pola pikirnya, sehingga pengetahuan yang diperolehnya semakin membaik (Cahyono, 2011).

Pendidikan merupakan proses perubahan dan peningkatan pengetahuan, pola pengetahuan, pola pikir dan perilaku masyarakat. Adanya dinamika berbagai aspek maka proses pendidikan akan terus menerus 
dan berkesinambungan sehingga masyarakat mampu menerima gagasan invasif secara rasional dan bertanggungjawab (BKKBN, 2009).

Jumlah anak yang masih hidup erat kaitannya dengan tingkat kesejahteraan. Keluarga dengan tingkat kesejahteraan tinggi, umumnya lebih mementingkan kualitas anak daripada kuantitas anak. Sementara itu pada keluarga miskin, anak dianggap memiliki nilai ekonomi. Umumnya, keluarga miskin lebih banyak mempunyai anak dibandingkan dengan keluarga dengan tingkat ekonomi menengah ke atas. Hal ini disebabkan karena pada umumnya keluarga miskin mempunyai tingkat pendidikan rendah atau menikah pada usia muda sehingga memiliki banyak anak (Nasution, 2011).

Antara pilihan metode kontrasepsi modern dan tradisional, terdapat hubungan yang positif antara paritas dan komposisi jenis kelamin anak terhadap penggunaan metode kontrasepsi modern saja (Jayaraman, Mishra \& Arnold, 2008). Makin banyak jumlah anak hidup yang dimiliki oleh pasangan, makin besar kecenderungan penggunaan metode kontrasepsi jangka panjang (Wang, 2010; Nasution, 2011).

Selain hal di atas, menurut Bertrand (1980) dalam Purba (2009), faktor-faktor yang mempengaruhi pemakaian kontrasepsi salah satunya adalah faktor Sosio-Demografi. Penerimaan KB lebih banyak pada mereka yang memiliki standar hidup lebih tinggi.

Tujuan dari penelitian ini adalah untuk mengetahui karakteristik responden yang menggunakan IUD post placenta di
Puskesmas wilayah Kabupaten Banjarnegara.

\section{METODOLOGI}

Penelitian ini menggunakan metode penelitian deskriptif dengan pendekatan waktu secara Cross Sectional. Populasi dalam penelitian adalah semua akseptor $\mathrm{KB}$ di Puskesmas wilayah Kabupaten Banjarnegara pada tahun 2017 yang berjumlah 50 orang. Teknik pengambilan sampel yang digunakan adalah teknik non probability sampling dengan teknik pengambilan accidental sampling. Sampel yang diambil adalah ibu post partum yang menggunakan IUD post placenta sebanyak 38 orang yang diambil berdasarkan kriteria inklusi, yaitu: bersedia menjadi responden, berdomisili di puskesmas wilayah bimbingan OSOC Kabupaten Banjarnegara. Kriteria eksklusi: ibu postpartum dengan perdarahan.

Tehnik pengumpulan data menggunakan data sekunder yang diperoleh dari RM yang ada di Puskesmas. Alat yang digunakan dalam penelitian ini adalah checklist yang berisi tentang karakteristik responden terdiri dari umur, paritas, pendidikan dan pekerjaan. Analisis data yang digunakan analisis univariat.

\section{HASIL DAN PEMBAHASAN}

a. Umur Akseptor Kontrasepsi IUD Post Placenta di Puskesmas wilayah Kabupaten Banjarnegara tahun 2017

Umur akseptor kontrasepsi IUD post placenta di Puskesmas wilayah Kabupaten Banjarnegara tahun 2017 dapat dilihat pada diagram di bawah ini. 


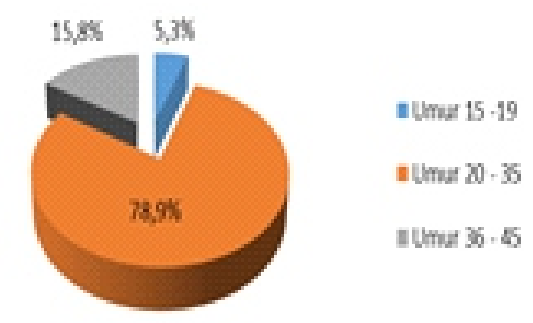

Diagram 1.1 Umur Akseptor Kontrasepsi IUD post placenta

Pada diagram 1.1 dapat dilihat bahwa umur responden terbanyak adalah pada kelompok umur 20-35 tahun yaitu 30 orang (78.9\%), sedangkan paling sedikit pada kelompok umur 15-19 tahun yaitu hanya 2 orang (5.3\%).

Hasil penelitian ini sesuai dengan teori Hartanto (2010) yang menyatakan bahwa umur berperan dalam pola pelayanan kontrasepsi kepada masyarakat yang berkaitan dengan memperhatikan kurun reproduksi sehat, dimana pada wanita dengan umur 2030/35 tahun merupakan fase menjarangkan kehamilan sehingga dibutuhkan alat kontrasepsi yang mempunyai efektivitas cukup tinggi, reversibilitas cukup tinggi karena peserta masih mengharapkan punya anak lagi, dapat dipakai 2-4 tahun yaitu sesuai dengan anak yang direncanakan, tidak menghambat ASI karena ASI adalah makanan terbaik untuk bayi sampai umur 2 tahun dan akan mempengaruhi angka kesakitan dan kematian anak maka dari itu alat kontrasepsi yang dijadikan pilihan utama adalah IUD dan KB suntik dapat dijadikan sebagai pilihan kedua.Menurut Wiknjosastro (2005), usia 20 30 tahun dianjurkan untuk menjarangkan kehamilan. Cara kontrasepsi yang dianjurkan salah satunya adalah AKDR.

Hasil penelitian ini juga sejalan dengan hasil penelitian Utami (2013) di RSUP DR. M. Djamil menyebutkan bahwa sebesar 79\% ibu pasca salin yangmenggunakan IUD pasca placenta adalah berumur 20-35 tahun.

\section{b. Pendidikan Akseptor Kontrasepsi IUD} post placenta di Puskesmas wilayah Kabupaten Banjarnegara tahun 2017

Pendidikan akseptor kontrasepsi IUD post placenta di Puskesmas wilayah Kabupaten Banjarnegara tahun 2017 dapat dilihat pada diagram di bawah ini.

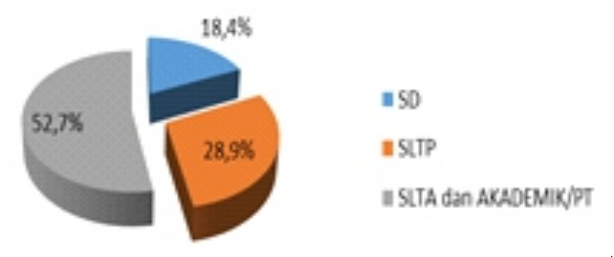

psi

Pada diagram 1.2 dapat dilihat bahwa pendidikan responden terbanyak adalah pendidikan tinggi (SLTA dan Akademik/PT) yaitu 20 orang $(52.7 \%)$, sedangkan paling sedikit adalah pendidikan SD yaitu hanya 7 orang $(18.4 \%)$.

Menurut Pastuti dan Siswanto (2007) menunjukkan bahwa responden yang berpendidikan tinggi secara signifikan berpeluang lebih tinggi untuk menggunakan IUD dan implan dibandingkan dengan responden yang berpendidikan rendah. Pendidikan merupakan faktor yang sangat menentukan pengetahuan dan persepsi seseorang terhadap pentingnya suatu hal termasuk pentingnya keikutsertaan dalam KB, karena seseorang yang berpendidikan tinggi lebih luas pandangannya dan lebih mudah 
menerima ide maupun hal-hal yang inovatif (Nasution, 2011).

Hasil penelitian ini sejalan dengan penelitian Utami (2013) dimana 49\% ibu pasca salinmenggunakan IUD post placenta adalah dengan pendidikan tinggi.

\section{c. Paritas Akseptor Kontrasepsi IUD post} placenta di Puskesmas wilayah Kabupaten Banjarnegara tahun 2017

Paritas akseptor kontrasepsi IUD post placenta di Puskesmas wilayah Kabupaten Banjarnegara tahun 2017 dapat dilihat pada diagram di bawah ini.

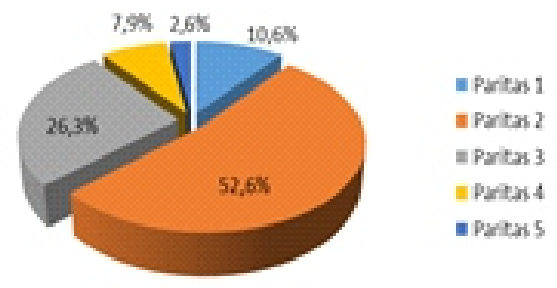

Diagram 1.3 Paritas Akseptor Kontrasepsi IUD post
placenta

Pada diagram 1.3 dapat dilihat bahwa paritas responden terbanyak adalah paritas dua yaitu sebanyak 20 orang (52.6\%), sedangkan paling sedikit adalah responden dengan paritas lima yaitu hanya 1 orang $(2.6 \%)$.

Menurut Suratun (2008) sebaiknya keluarga keluarga setelah mempunyai 2 anak dan umur istri lebih dari 30 tahun tidak hamil lagi. Kondisi keluarga seperti ini dapat menggunakan kontrasepsi yang mempunyai efektifitas tinggi, karena jika terjadi kegagalan hal ini dapat menyebabkan terjadinya kehamilan dengan risiko tinggi bagi ibu dan anak. Di samping itu jika pasangan akseptor tidak mengharapkan untuk mempunyai anak lagi, kontrasepsi yang paling cocok disarankan adalah IUD.

Hasil penelitian ini tidak sejalan dengan teori Subiyatun dkk (2010) yang menyatakan bahwa jumlah anak mempengaruhi pemilihan kontrasepsi yang akan digunakan. Semakin banyak anak yang dimiliki maka akan semakin besar kecenderungan untuk menghentikan kesuburan sehingga lebih cenderung untuk memilih MKJP yang salah satunya adalah IUD.

Hasil penelitian ini sejalan dengan penelitian Tirfe (2013) yang menunjukan bahwa jumlah anak hidup $1-3$ orang $(66,9 \%)$ cenderung memilih jenis kontrasepsi IUD. Hasil penelitian Lakew et.al. (2013), jumlah anak yang hidup seorang wanita memiliki pengaruh secara signifikan terkait dengan penggunaan metode kontrasepsi modern. Seorang wanita yang memiliki setidaknya satu anak memiliki kemungkinan lebih tinggi menggunakan alat kontrasepsi modern dari wanita yang tidak memiliki anak.

\section{d. Pekerjaan Akseptor Kontrasepsi IUD} post placenta di Puskesmas wilayah Kabupaten Banjarnegara tahun 2017

Pekerjaan akseptor kontrasepsi IUD post placenta di Puskesmas wilayah Kabupaten Banjarnegara tahun 2017 dapat dilihat pada diagram di bawah ini.

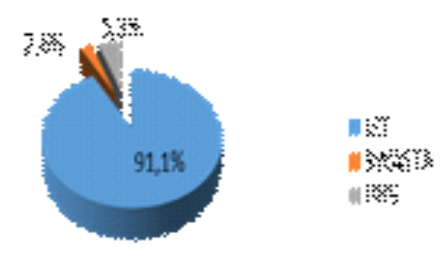

Diagram 1.4 Pekerjaan Akseptor Kontrasepsi IUD post placenta 
Pada diagram 1.4 dapat dilihat bahwa pekerjaan responden terbanyak adalah IRT yaitu sebanyak 35 orang (91.1\%), sedangkan paling sedikit adalah swasta yaitu hanya 1 orang $(5.3 \%)$.

Hasil penelitian ini tidak sesuai dengan hasil penelitian Amiranty (2003) yang menunjukkan bahwa ibu yang bekerja memiliki peluang sebesar 2 kali untuk memakai MKJP dibandingkan dengan ibu yang tidak bekerja.

Pada penelitian ini sebagian besar responden adalah sebagai IRT, sehingga hasil penelitian ini tidak sama dengan teori yang dikemukakan oleh Heriati (2013) yang menyatakan bahwa seseorang yang bekerja cenderung lebih mudah menerima informasi guna menambah pengetahuannya termasuk tentang metode kontrasepsi. Ibu yang bekerja akan lebih memilih metode kontrasepsi yang memiliki tingkat efektifitas tinggi dan bertahan jangka panjang seperti IUD Post Placenta sehingga ibu dapat lebih nyaman dalam bekerja dan keluarga sejahtera.

Status pekerjaan ibu tidak mempengaruhi pemilihan alat kontrasepsi karena pemilihan alat kontrasepsi dapat disebabkan oleh faktor yang lain seperti jumlah anak, usia pernikahan serta kecocokan terhadap alat kontrasepsi.

\section{SIMPULAN DAN SARAN}

\section{a. Simpulan}

Kesimpulan dalam penelitian ini adalah sebagian besar responden pada kelompok umur 20-35 tahun yaitu 30 orang (78.9\%), pendidikan responden sebagian besar SLTA dan Akademik/PT yaitu 20 orang (52.7\%), paritas responden sebagian besar adalah paritas dua yaitu sebanyak 20 orang (52.6\%) dan pekerjaan responden sebagian besar adalah IRT yaitu sebanyak 35 orang (91.1\%).

\section{b. Saran}

Puskesmas diharapkan meningkatkan pelayanan KB melalui penyuluhan dan konseling kepada calon akseptor KB khususnya jenis KB IUD post placenta dan masyarakat diharapkan meningkatkan pemahaman terhadap KB serta dapat memilih alat kontrasepsi yang memiliki efektifitas tinggi seperti IUD post placenta.

\section{DAFTAR PUSTAKA}

Amiranty, Mira. 2003. Faktor-faktor yang Berhubungan dengan Pemakaian Metode Kontrasepsi Pada Akseptor KB di Propinsi Maluku dan Papua pada Tahun 2001 (Analisis Data Sekunder Sosial Ekonomi Nasional 2001). Depok: Skripsi FKM UI.

Badan Pusat Statistik. 2009. Statistik Indonesia. Jakarta: BPS.

BAPPENAS. 2007. Laporan Pencapaian Millenium Development Goals Indonesia. Jakarta: Badan Perencanaan Pembangunan Nasional dan UNDP.

BKKBN. 2010. IUD Post Placenta Sebagai Solusi Ber Kb. Diakses 17 Juni 2017. $\mathrm{T}$ e $\mathrm{rd}$ a $\mathrm{p}$ a $\quad \mathrm{p} \mathrm{a} \mathrm{d} \mathrm{a}$ http://www.bkkbn.go.id

BKKBN. 2016. Petunjuk Teknis Kampung KB. Diakses 17 Juni 2017. Terdapat pada : http://sakura.bkkbn.go.id

BKKBN. 2009. Hasil Analisa Lanjut SKDI 2007. Jakarta : Badan Kependudukan dan Keluarga Berencana Nasional BKKBN. Pedoman pelayanan KB dalam jaminan kesehatan masyarakat. .

Heriati, D. 2013. Faktor-Faktor Yang Mempengaruhi Pengetahuan Ibu Tentang Penggunaan Iud Post placenta Di Rumah Sakit Umum Daerah Dr. Zainoel Abidin. 
Banda Aceh: KTI. STIKes U'budiyah. 2013

Nasution SL. 2011. Faktor-Faktor Yang Mempengaruhi Penggunaan MKJP di Enam Wilayah Di Indonesia. Pusat Penelitian dan Pengembangan KB. Jakarta: BKKBN.

Lakew, Y., 2013. Reda, A.A., Tamena, H., Benedict, S., Deribe, K. Geographical Variation And Factors Influencing Modern Contraceptive Use Among Married Women In Ethiopia: Evidence From A National Population Based Survey. Reproductive Health

Rencana Pembangunan Jangka Menengah Daerah. 2011-2016. Jumlah Peserta KB Aktif. Banjarnegara: RPJM Daerah

Subiyatun S, Dasuki D dan Budi W. 2010. Hubungan Antara Pemberian Informasi Dengan Pemilihan Metode Atau Alat Kontrasepsi Rasional. Jurnal Kebidanan Dan Keperawatan, Vol 5. No 2. Desember 2010.

Utami, S. Desmiwati dan Endrinaldi. 2013. Faktor - Faktor Yang Berhubungan Dengan Unmet Need Pasca-Salin IUD PostPlasenta Di Kamar Rawat PascaBedah RSUP DR. M.Djamil Periode JanuariMaret 2013.

Suratun, dkk. 2008. Pelayanan Keluarga Berencana dan Pelayanan Kontrasepsi. Jakarta:TIM

Pastuti, R. Dan Siswanto A.W. 2007. Determinan Penggunaan Kontrasepsi IUD di Indonesia, Analisis Data SDKI 2002-2003. Berita Kedokteran Masyarakat.

Laguna, E.O., A.L.C., Perez, A.E. 2000. Contraceptive Use Dynamics In The Philippines: Determinants Of Contraceptive Method Choice And Discontinuation. Quezon City: Population Institute University of the Philipines. Diunduh pada 17 Juni 2017

Cahyono B.e., 2011. Faktor-faktor Yang Mempengaruhi Ketidaklangsungan pemakaian Kontrasepsi IUD di
Indonesia (Analisis SDKI 2007). Tesis. Universitas Indonesia

Wang, C. 2010. Trends In Contraseptive Use And Determinants of Choice In China: 1980-2010. School of Social Development, Central University of Fiannce and Economics, Beijing, China

Wiknjosastro, H. 2005. Ilmu Kebidanan. Jakarta : Yayasan Bina Pustaka Sarwono Prawirohardjo 